\title{
Knowing the Basics About 4-H Clubs ${ }^{1}$
}

Marilyn N. Norman and Joy C. Jordan ${ }^{2}$

\section{What is a 4-H Club?}

The 4-H club serves as the primary means of providing youth development programming in 4-H. It has the advantage of long-term involvement with the support of caring adults.

4-H clubs are organized and supported to provide community based positive structured learning opportunities for youth throughout their developmental years. While other 4-H delivery methods are effective, more in-depth experiences occur in and through the club.

The goals and structure of 4-H clubs vary according to the needs of the members they serve. Some clubs offer one project topic the entire membership experiences together at the club meeting. Others offer a selection of projects delivered through project meetings held at times outside the club. Some clubs have a singular geographic focus such as community service clubs, or they serve specific audiences such as tribal reservation clubs, after school clubs or home school clubs. But there are components and characteristics common to all 4-H clubs and these commonalities provide the definition of a 4-H club.

A 4-H Club:

- Is an organized group of youth.

- Has a planned program that is ongoing throughout all or most of the year.

- Is advised by adult staff or volunteers.

- Typically elects officers.

- May meet in any location.
- Includes opportunities to learn skills through project experiences.

- Offers opportunities for leadership, citizenship/community service, and public speaking.

Surveys of youth who have been involved in out-ofschool youth programs report the importance youth place on knowing that programs will continue over many years. Youth are reluctant to take ownership in groups or establish relationships with volunteers when either appears temporary.

\section{Who can join?}

Youth ages 5-18 (as of September 1 of the current year or not having graduated from high school) are eligible to be 4-H members in Florida. Many organized clubs do serve youth across the age span of 5 to 18 .

Counties in Florida have the option to support younger members (5 to 7 years) called Cloverbuds. These clubs require additional volunteers, especially to support the younger youth, ages 5 to 7 . Where these clubs exist, they focus on cooperative learning and do not participate in competitive events.

\section{Criteria for 4-H Youth Development Programming Including 4-H Clubs}

Both National and State 4-H Headquarters, located at USDA Cooperative State Research Education and Extension Service (CSREES) and the University of Florida (UF), have policies governing 4-H clubs.

\footnotetext{
${ }^{1}$ This document is 4-H S FS101.6, one of a series of the Florida 4-H Program, Florida Cooperative Extension Service, Institute of Food and Agricultural Sciences, University of Florida. This material is based upon work supported by the Cooperative Research, Education, and Extension Service, US Department of Agriculture, and K-State Research and Extension, Kansas State University, under special project number 99-EYAR-1-0747. This 4-H 101 Handbook was developed by the 4-H 101 Design Team chaired by Andrea Hutson, USDA/Army Youth Development Project, CSREES/Virginia Tech University. It was adapted for Florida by Marilyn N. Norman and Joy C. Jordan, State 4-H Program. Published May 2006. Please visit the 4-H Website at http://4h.ifas.ufl.edu/Curriculum/index.html.

${ }^{2}$ Marilyn Norman, Associate Professor in Family Youth and Community Sciences, and State 4-H Program Leader, and Joy C. Jordan, Associate Professor in Family, Youth and Community Sciences, Institute of Food and Agricultural Sciences, University of Florida, Gainesville.

The Institute of Food and Agricultural Sciences (IFAS) is an Equal Employment Opportunity - Affirmative Action Employer authorized to provide research, educational information and other services only to individuals and institutions that function without regard to race, creed, color, religion, age, disability, sex, sexual orientation, marital status, national origin, political opinions or affiliations. For information on obtaining other extension publications, contact your county Extension Service office. The Florida 4-H Program is the youth development program of the Florida Cooperative Extension Service/Institute of Food and Agricultural Sciences/University of Florida/Larry R. Arrington, Dean.
} 
These policies govern all youth development programming delivered through 4-H.

- 4-H programs, curricula, and procedures are based in research and are developmentally appropriate.

- 4-H programs are based on the needs of children, youth and their parents.

- 4-H provides access to resources of the Land Grant University Cooperative Extension System.

- 4-H provides members access to county, state, and national 4-H opportunities.

- 4-H membership is open to all youth.

- 4-H programs employ experiential learning strategies.

- 4-H encourages active involvement and participation by children, youth, and adults in all aspects.

- 4-H relies heavily on youth and adult volunteers or staff to provide a critical support system.

- 4-H provides training for volunteer and staff recognizing that training is essential for effective 4-H programs.

- 4-H adapts to and supports mobility of children/youth and parents.

- 4-H clubs comply with national 4-H name and emblem policies and policies of the state.

\section{Types and Characteristics of Clubs}

\section{Organized 4-H Clubs}

The 4-H club is one of the most effective methods used by the 4-H program. 4-H clubs are organized groups of boys and girls supported by adult volunteers. The 4-H club conducts meetings and activities throughout the year - usually holding six or more official meetings annually. Club meetings typically include the conducting of some business by the officers, an educational program, and a group building or recreational activity. The club frequently includes opportunities for leadership, citizenship, and public speaking. It may meet in any location and is authorized through the county and state Extension Office to use the 4-H name and emblem.

In all clubs, members are encouraged to learn and participate in one or more projects. Additionally clubs do a community service or service learning project during the $4-\mathrm{H}$ year. All clubs require at least one designated adult club volunteer.

There are different methods and locations of organizing 4-H clubs. Clubs may be formed in communities, in schools, in after-school settings, on military installations or via the internet. Two distinctive types of methods or organizational structure exist: clubs where youth have multiple interests or a singular focus.

\section{Multi-Project or General Club}

The multi-project or general club provides an opportunity for youth to plan and conduct their own program with the guidance of adult volunteer(s). These clubs usually have elected youth officers, develop their own club name, create by-laws, and learn to govern themselves. The club: 1) meets regularly to conduct a business meeting; 2 ) provides an educational program or activity (often by the youth themselves); 3) addresses county and community issues through community service projects and (4) offers a selection of projects delivered through project meetings held at times outside the club meeting. This format provides a wider choice of learning experiences for the 4-H'er but requires more volunteers for the additional project meetings. It is more complicated than single project clubs to manage.

\section{Project Clubs}

Clubs that (1) meet regularly, (2) conduct a business meeting, (3) address county and community issues through service, and, (4) focus on one project for the entire membership, are referred to as project clubs.

In a single-project club, all the members are enrolled in the same project; they may be active in more than one project club.

\section{Supplemental Learning Activities}

In addition to the many activities scheduled in club meetings, 4-H members in all clubs are provided access to additional structured learning opportunities though:

- Community Service projects;

- Day Camps;

- Overnight camping;

- Trips;

- Events and Activities:

o Competitive Events and Activities (fairs, judging etc.) and

o Non-Competitive Events and Activities (projects, dances, lock-ins, retreats, seminars, etc.). 


\section{Starting and Maintaining 4-H Clubs}

\section{Enrollment Procedures}

Enrollment of clubs and all members and volunteers or leaders is required for participation. This enrollment is done through the county and periodically submitted to the state office. The county 4-H office has the necessary

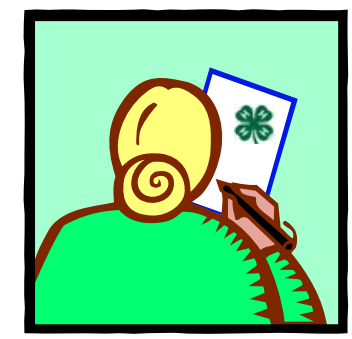
forms and instructions for completion. Most 4-H offices use a computer enrollment system, which means the forms must be filled out completely and accurately. The 4-H program year operates from September 1 through August 31.

\section{Establishing and Chartering a 4-H Club}

Florida has established criteria for enrolling as an official 4- $\mathrm{H}$ Club. Official enrollment as a 4-H Club and receipt of a 4-H Club charter gives the club the authority to use the 4-H name and emblem. Clubs must be chartered through a request to the local Extension Office, meeting the minimum criteria and a signature request for a charter. Criteria for clubs in Florida are as follows:

- The club has five members (from at least two families) with completed enrollments.

- The club is organized with youth officers.

- There are one or more appointed (through application/screening) and trained club volunteers.

- An initial meeting place is secured for at least several consecutive months.

- An official non-discriminatory club name is chosen

- Club rules, which may be in the form of by-laws, are established.

- At least six or more regular meetings plus project meetings are scheduled.

- A written educational plan for the club program and activities is presented to the county $4-\mathrm{H}$ office (draft is okay).

A copy of the club enrollment is kept on file with the County Extension office. When requesting a Club Charter the Charter Application Form should be completed by the Club Secretary and signed by the Club President, Club Volunteer, and Extension Faculty. Once completed, the Extension Faculty will then forward the request to the State 4-H Office. This form can be found at the Florida $4-\mathrm{H}$ website listed at the end of this document.
Official Chartered 4-H Club can use the name and emblem of 4-H. Individual clubs may have continuous use of their charter over many years, however, an annual Request for Continuance, is required from all clubs. This form can be found at the Florida 4-H website listed at the end of this document. Counties usually require this form to be completed upon the re-enrollment of individual members annually during the fall. The annual 4-H calendar follows a program year operating September 1 through August 31. A letter from the County Extension Office will acknowledge continued club status annually.

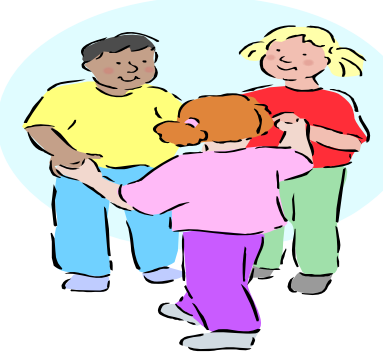

\section{Enrolling Members}

Youth may join 4-H at any time and clubs may be formed throughout the year. Enrollment forms of new members and volunteers who join the club during the year should be submitted immediately to the county 4-H office by the club volunteer.

However, many counties promote and recruit new members and "re-enroll" clubs and their membership each fall. Annually, an "enrollment due date" for returning members of 4-H Clubs will be determined by the county 4-H faculty. Enrollment forms include choices for projects, releases for use of photographs or program evaluation tools, and agreements for non-discriminatory membership. Often a state 4-H membership code of conduct/volunteer expectations must be read and signed and submitted with the enrollment form. The Individual Youth Enrollment Form and 4-H Participation Form are located at the Florida 4-H website listed at the end of this document.

Eligibility for competition at fairs or exhibitions, and some project involvement requirements are often determined by birth date as of September 1 of the current program year or grade in school. Other requirements may also be in place at the county level. Competitive event guidelines and supporting information can be obtained from your County 4-H Extension faculty. 


\section{Enrolling Volunteers}

Florida requires a screening and training process prior to serving as an official 4-H volunteer and working directly with youth. Position descriptions that

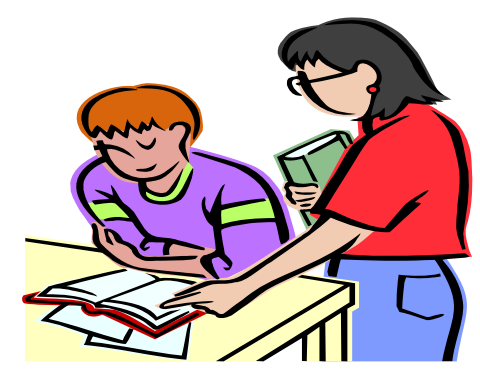
outline leader responsibilities are usually provided. Every Extension volunteer who works directly with youth on an on-going basis (3 or more times annually) or for an overnight situation must complete the 4-H Volunteer Screening process.

The Florida 4-H Volunteer Application Forms are located at the Florida 4-H website listed at the end of this document.

Throughout the year, youth, staff, and volunteers who participate in special programs beyond the club level (e.g., County 4-H Camp, State 4-H Congress, State Leader's Forum, National Tech Conferences) are required to complete additional forms such as health information, parent/ guardian permission, code of ethics, etc. which relate to the specific event.

\section{Fiscal Requirements of 4-H Clubs}

A 4-H club must be chartered to be eligible to use the name and emblem of 4-H. Chartered clubs have several rights and responsibilities for fiscal

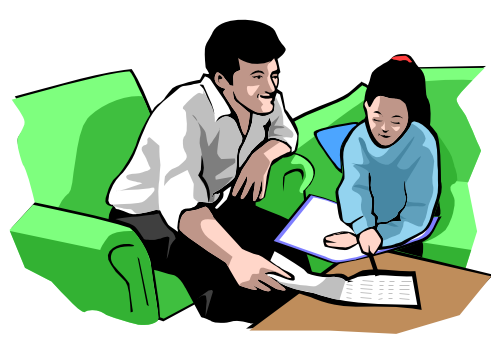
management of resources garnered in the name of 4-H. All individual clubs in Florida operate under the fiscal authority and jurisdiction of the County Extension Director. How club accounts are managed varies with counties, but regardless of method, no individual staff, youth, or adult volunteer names should appear on any checking/savings account of a 4-H club account.

4-H Clubs are exempt from the payment of Federal income taxes. The ruling was issued to the Department of Agriculture by the Internal Revenue Service on April 24, 1946, which recognized that 4-H Clubs were exempt from federal income tax under section 101(6) of the Internal Revenue Code of 1939, which corresponds to section 501(c) (3) of the 1986 Code.
Club treasuries and fundraising activities have specific guidelines and procedures to follow. As clubs are formed, club treasurers and designated adult leaders will receive training and materials regarding county 4-H club fiscal policies.

\section{Member Fees/Dues}

Some counties require 4- $\mathrm{H}$ members to pay registration membership dues, and some do not. Sometimes counties may assess fees to cover the cost of insurance, newsletters, or other specified items.

\section{Insurance/Risk Management}

Liability and accident insurance information is provided for county personnel in the 4-H Program Handbook. If it is not available, it will be important that volunteers and parents contact the state or county office to obtain the information. Ensuring proper coverage for members and volunteers is extremely important and protects individuals and the organization. 4-H volunteers will want to ask your county Extension agent for information and forms concerning insurance coverage available to the $4-\mathrm{H}$ club.

\section{Evaluating, Reporting, and Recognizing Club Performance}

4-H Extension agents report data to the University of Florida and CSREES/USDA in an annual statistical report of summarized demographic data regarding members and volunteers. This information includes the numbers of clubs in the county, member enrollment and project information about the program. Youth development professionals working with an organization outside Extension, will need to work closely with the county 4-H Extension faculty and include data on the club in this report.

In addition to the statistics gathered about the 4- $\mathrm{H}$ club, volunteers will want to evaluate the success of the club in providing the support youth need. This will allow club volunteers to state how well the club is contributing to the growth and development of its members. This assessment involves more than gathering numbers. While the numbers of youth participating does indicate a level of success in reaching youth (they keep coming, or drop out), there are other indicators that will help assess what is happening in the club. Work closely with the 4-H Extension faculty and use quality evaluation tools to assess club progress. 


\section{Club Performance}

Recognition

Club recognition systems exist to recognize clubs for their performance. Clubs

may strive to reach specific

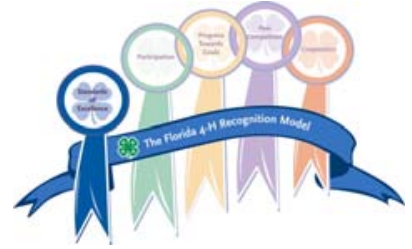

standards of performance just as individual club

members work to achieve standards. Florida 4-H provides four levels of recognition - bronze, silver, gold, and emerald - for 4-H Club attainment. These standards can be found at the Florida $4-\mathrm{H}$ website under Awards and Recognition Programs.

For further information about the Florida 4-H Program go to the Florida 4-H web site at: http:///www.florida4h.org 